\title{
RANCANG BANGUN SISTEM INFORMASI KOPERASI SIMPAN PINJAM KARYAWAN STUDI KASUS PT NON FERINDO UTAMA
}

\author{
Ivan Nur Amanda \\ Program Studi Informatika \\ Fakultas Teknik Universitas Muhammadiyah Tangerang \\ Jl. Perintis Kemerdekaan 1/33 Cikokol Kota \\ ivannuramanda@yahoo.com
}

\begin{abstract}
Employee Cooperative PT Non Ferindo Utama is a cooperative engaged in the Savings and Loans and Shop Business to serve all members of the Cooperative. Cooperative objectives in general for member welfare, business continuity growth and positive responses from the community. In efforts to achieve these objectives, will certainly be directly related to processing planning and data management. Processing and management of data is required as a convenience and security and effectiveness in handling it to obtain maximum results. Errors and data insecurity mostly occur in an institution, high school and company because handling, storing, and repair data kebanyaan done manually. With the implementation of the Information System Cooperative Savings and Loans Employees At PT. Non Ferindo Utama - Tangerang by using a Java programming language in the process will greatly help the Cooperative to do all the work related to the data arrangement by using the new system.
\end{abstract}

Keywords: Cooperative, Systems, Data, Computerized, Java.

\section{PENDAHULUAN}

Ilmu Teknik Informatika adalah suatu ilmu yang sangat berhubungan erat dengan teknologi informasi, dimana penerapannya mengarah kepada kemajuan teknologi masa depan. Perkembangan dunia teknologi informasi saat ini sangat cepat karena didorong oleh kebutuhan data dan informasi.

Koperasi Karyawan PT Non Ferindo Utama "KONFERTA", dalam mengelola data usaha tersebut masih menggunakan cara manual dan sistem komputer yang masih sederhana yaitu menggunakan Microsoft Office Excel dalam mencatat setiap transaksi, baik transaksi penjualan maupun transaksi simpan pinjam. Hal ini dirasakan tidak efektif karena untuk penyusunan laporan maupun penghitungan laba rugi memerlukan waktu yang lama dan cara yang rumit.
Dengan ditingkatkannya pelayanan terhadap anggota, maka diharapkan dapat meningkatkan profesionalitas dalam pelayanan terhadap anggota maupun dalam pengelolaan administrasi. Keberhasilan itu tentunya tidak terlepas dari sistem informasi dan teknologi yang bersifat relevan, akurat, lengkap dan tepat waktu. Semua itu menjadi faktor pendukung untuk mencapai tujuan koperasi pada umumnya yaitu mencapai laba yang maksimal, mempertahankan kelangsungan usaha, dan mengejar pertumbuhan dalam usahanya.

Berdasarkan permasalahan tersebut maka penulis mengusulkan untuk membuat sistem koperasi simpan pinjam karyawan

A. Identifikasi Masalah 
Berdasarkan latar belakang yang telah diuraikan, beberapa permasalahan yang dapat diidentifikasi dalam penelitian ini antara lain :

1. Proses pengolahan data seperti data Simpan pinjam anggota dilakukan menggunakan software microsoft excel tetapi belum terkomputerisasi (masih manual).

2. Dibutuhkan suatu sistem informasi untuk membantu admin koperasi dalam membuat laporan.

\section{B. Batasan Masalah}

Batasan masalah dalam penelitian ini adalah

1. Penelitian ini meliputi fitur koperasi simpan pinjam di PT Non Ferindo Utama.

2. Penelitian ini menggunakan Bahasa pemrograman Java untuk pembuatan sistem informasi koperasi berbasis aplikasi.

\section{Rumusan Masalah}

Bagaimana merancang sistem informasi koperasi simpan pinjam di PT Non Ferindo Utama dengan Bahasa pemrograman Java?

\section{TINJAUAN PUSTAKA}

\section{A. Sistem}

Menurut Jogianto, suatu sistem adalah merupakan jaringan dari prosedur-yang saling berhubungan, untuk melakukan suatu kegiatan atau untuk menyelesaikan suatu sasaran tertentu

Suatu sistem mempunyai karakteristik sebagai berikut :

1. Suatu sistem dapat terdiri dari komponen (Component) yang saling berinteraksi yang bekerja sama membentuk satu kesatuan komponen sistem atau elemen

2. Batas Sistem (Boundry) yang membatasi antara sistem yang satu dengan sistem yang lainnya.

3. Lingkungan luar (Environment )dari suatu sistem diluar batas dari sistem yang mempengaruhi operasi sistem.

4. Penghubung (interface) merupakan media penghubung antara satu subsistem dengan subsistem yang lainnya

5. Memiliki input yang akan di olah di dalam sistem
6. Adanya output yang di hasilkan dari input yang dimasukan ke dalam system

7. Suatu sistem dapat mempunyai suatu bagian pengolahan ( Process ) yang akan mengolah input berupa data serta bahanbahan lainnya untuk menghasilkan output berupa laporan ddan informasi yang berguna.

8. Sistem pasti mempunyai tujuan(goal) atau sasaran (objective). Kalau suatu sistem tidak mempunyai sasaran maka proses operasi tidak akan ada gunanya.

\section{B. Informasi}

Menurut Sutanta (2004) Informasi dapat didefinisikan sebagai hasil pengolahan data sehingga menjadi bentuk yang penting bagi penerimanya dan mempunyai kegunaan sebagai dasar dalam pengambilan keputusan yang secara langsung dapat dirasakan akibatnya atau secara tidak langsung pada waktu yang akan datang.

\section{METODOLOGI PENELITIAN}

\section{A. Metode Penelitian}

PT.Non Ferindo Utama merupakan industri daur ulang aki bekas yang telah memperoleh ijin dari Kementrian Lingkungan Republik Indonesia. Didirikan pada tahun 1986 dan beroperasi 1 tahun kemudian. Dalam operasional usahanya PT.Non Ferindo Utama adalah industri daur ulang aki bakas yang ramah lingkungan karena menggunakan teknologi dan peralatan mutahir.

Dalam Penelitian ini menggunakan metode pengumpulan data dengan cara observasi dan wawancara di PT. Non Ferindo Utama untuk mendapatkan infromasi apa yang dibutuhkan dalam membuat sistem informasi koperasi simpan pinjam.

Untuk mengidentifikasi masalah, maka dilakukan analisis terhadap beberapa aspek seperti kinerja, informasi, ekonomi, pengendalian, efisiensi, dan pelayanan. Analisis dengan menggunakan model ini dikenal dengan analisis PIECES (Performance, Information, Economic Control, Efficiency, Service). Hasil dari analisis yang di dapat sebagai berikut :

1. Performance : 
a. Pembuatan laporan yang belum up to date

b. Pengelolaan transaksi simpan pinjam tidak bisa cepat terselesaikan karena kesulitan dalam mencari data.

c. Tidak ada security untuk menjaga keamanan dari data yang dianggap confidential.

2. Information :

Masih adanya kesalahan penghitungan dalam transaksi simpan pinjam yang berkaitan terhadap pembuatan laporan yang tidak sesuai tepat waktu.

3. Economy : Proses administrasi koperasi masih menggunakan media buku sehingga memerlukan banyak biaya.

4. Control : Perusahaan masih melakukan kontrol laporan koperasi secara manual

5. Efficiency : Efisiensi dalam pembuatan laporan simpan pinjam masih kurang dan tidak efisien

6. Service : Pelayanan koperasi perusahaan masih belum optimal.

\section{ANALISIS DAN PEMBAHASAN}

\section{A. Analisis Data}

Dari permasalahan yang timbul di atas, ada beberapa alternatif yang bisa diusulkan, seperti:

1. Membuat sistem informasi simpan pinjam berbasis aplikasi.

2. Membuat proses administrasi yang lebih. sistematis dalam penggunaannya.

Ada beberapa alasan mengapa sistem koperasi simpan pinjam ini dibuat dan dikembangkan menjadi aplikasi :

1. Sistem informasi koperasi ini dapat memudahkan pengurus koperasi dalam seluruh proses administrasi sehingga para pegawai dapat memperoleh informasi data sebelum dengan mudah dan cepat.

2. Dengan adanya sistem informasi koperasi ini dapat mempercepat proses pengelolaan transaksi simpan pinjam, karena mudah dalam pencarian data.

Penyajian suatu sistem informasi sedemikian rupa dibuat untuk dapat di akses dengan memanfaatkan teknologi yang ada. Hal ini harus disertai dengan kemudahan dalam pengoperasian dan biaya yang relatif murah.

\section{B. Economic Feasibility}

Aspek dalam sisi ekonomi meliputi biaya yang dikeluarkan untuk membangun sistem dan membandingkan dengan manfaat yang akan didapat setelah sistem koperasi ini akan berjalan.

Pengembangan sistem koperasi ini dapat dianggap sebagai sebuah investasi jangka panjang yaitu dengan pengeluaran sumber daya yang ada sekarang untuk mendapatkan manfaat diwaktu yang akan datang. Apabila manfaat yang didapat lebih kecil dari biaya yang dikeluarkan, maka pengembangan sistem ini dianggap tidak perlu.

\section{Organizational Feasibility}

Beberapa manfaat yang didapat kan dalam penggunaan sistem informasi koperasi ini diantaranya dibagi menjadi:

\section{Bagi perusahaan}

1. Memudahkan perusahaan dalam mengontrol keuangan dari laporan koperasi.

2. Meningkatkan citra perusahaan dalam komputerisasi proses di bagian koperasi.

3. Mendapatkan laporan yang up to date tentang operasional koperasi

\section{Bagi staf koperasi}

1. Mempermudah dalam pencarian data sehingga pengelolaan transaksi simpan pinjam bisa cepat terselesaikan

2. Membantu dalam proses perhitungan transaksi simpan pinjam sehingga tidak ada lagi kesalahan penghitungan dan pembuatan laporan bisa sesuai tepat waktu.

\section{Activity Diagram}

Activity Diagram adalah diagram untuk menggambarkan aktifitas dari suatu sistem atau proses suatu bisnis, Activity Diagram yang diusulkan untuk proses simpan pinjam sistem koperasi ini sebagai berikut : 


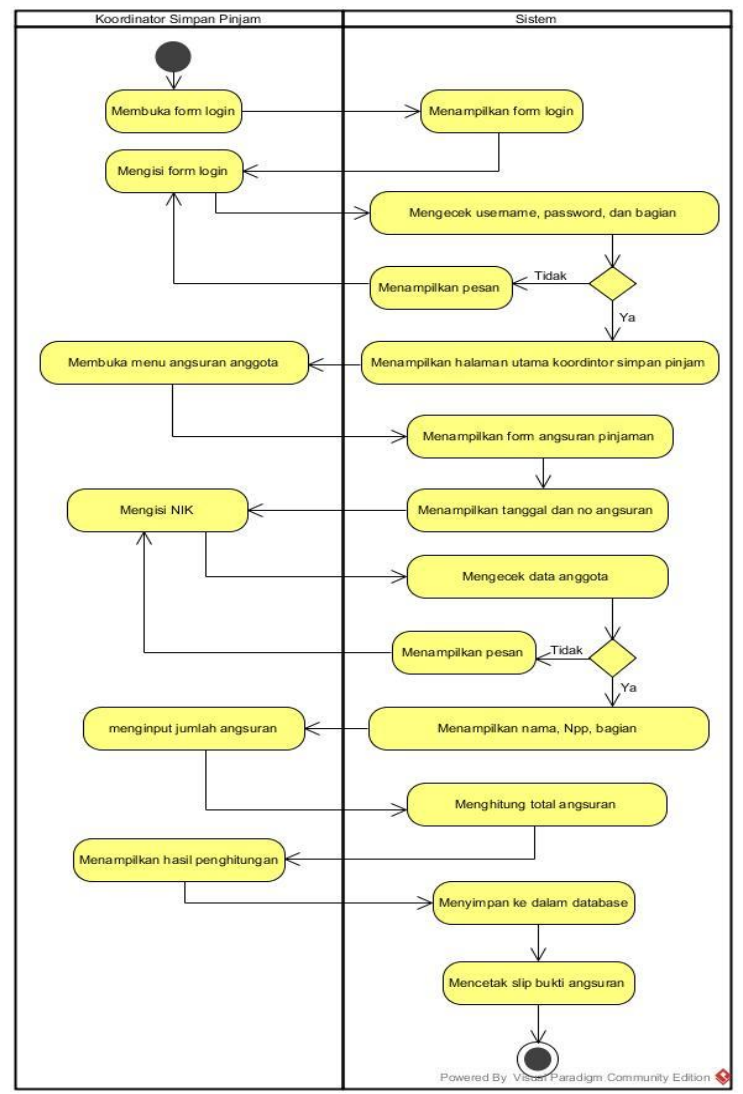

Gambar 1 Activity Diagram proses Simpan

Proses pertama dari pinjaman di koperasi. Proses ini dimulai dengan staff dari koperasi dalam hal ini koordinator melakukan login dengan user dan password yang telah dibuat. Dalam proses ini sistem akan mengecek apakah data login yang dimasukkan sudah benar, apabila ada kesalahan maka sistem akan menampilkan pesan error.

Apabila proses login berhasil, maka akan masuk ke menu utama dari sistem ini. Apabila ingin melakukan proses pinjam maka dipilih menu Angsuran Anggota. Setelah masuk ke menu tersebut maka dimasukkan NIK dari anggota koperasi yang ingin melakukan pinjaman.

Sistem akan menampilkan dari NIK anggota koperasi dan user hanya perlu memasukkan jumlah angsuran yang ingin di proses, sistem akan menghitung otomasis dan menampilkan hasil dari perhitungan tersebut.

Apabila di terima untuk peminjaman ini maka akan disimpan dalam database dan user hanya tinggal mencetak slip tanda bukti angsuran dan menyerahkan kepada anggota.

\section{E. Implementasi Sistem}

Implementasi sistem adalah hasil penerapan dari rancangan menu yang telah di buat. Perancangan aplikasi ini menggunakan Bahasa pemrograman Java.
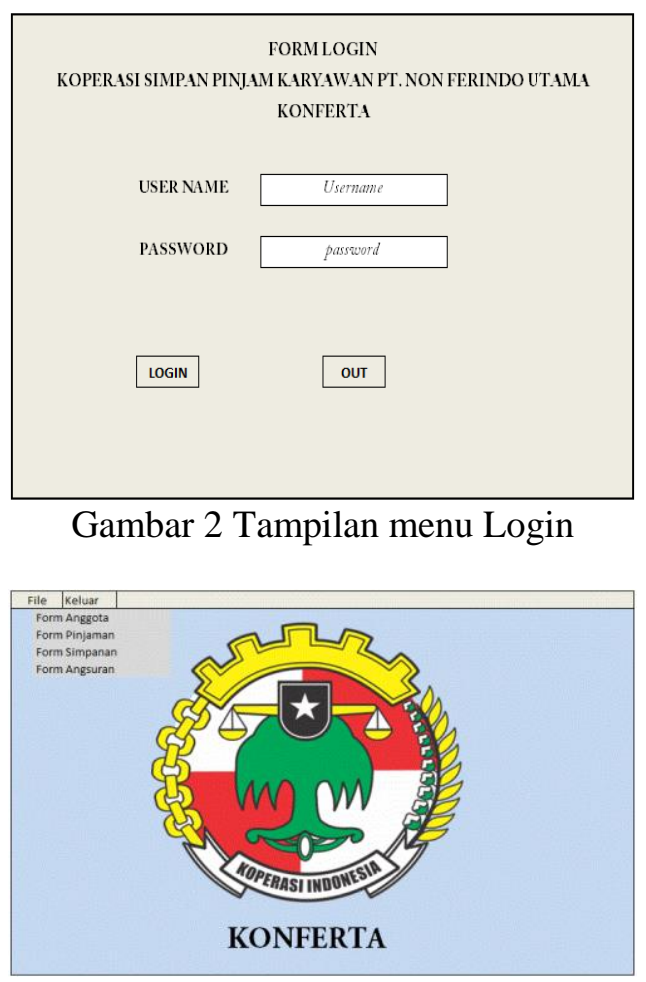

Gambar 3 Tampilan Halaman Utama

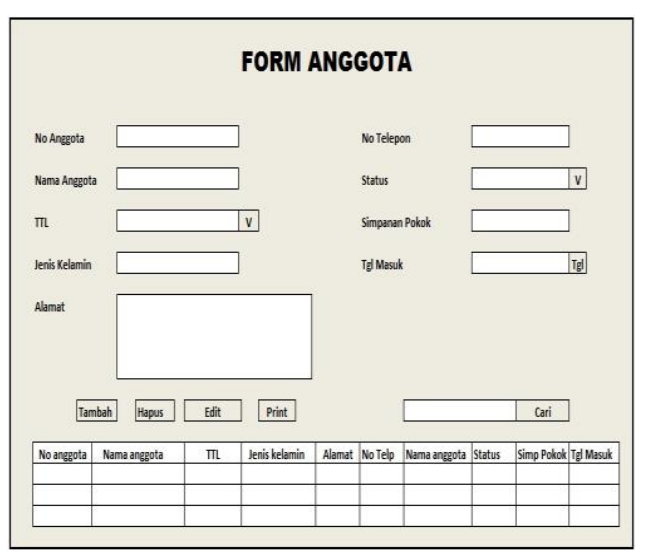

Gambar 4 Form Input Anggota 


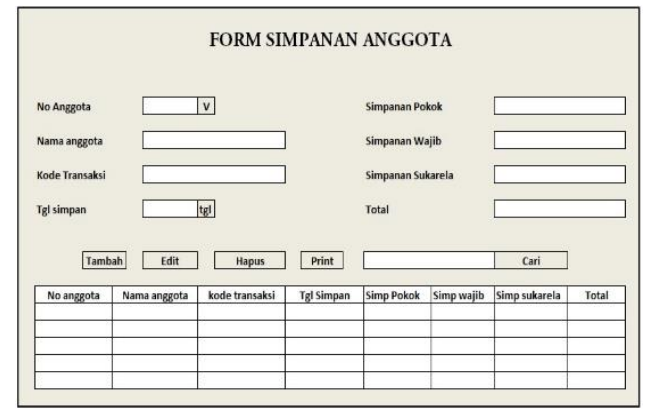

Gambar 5 Form Input Data Simpanan

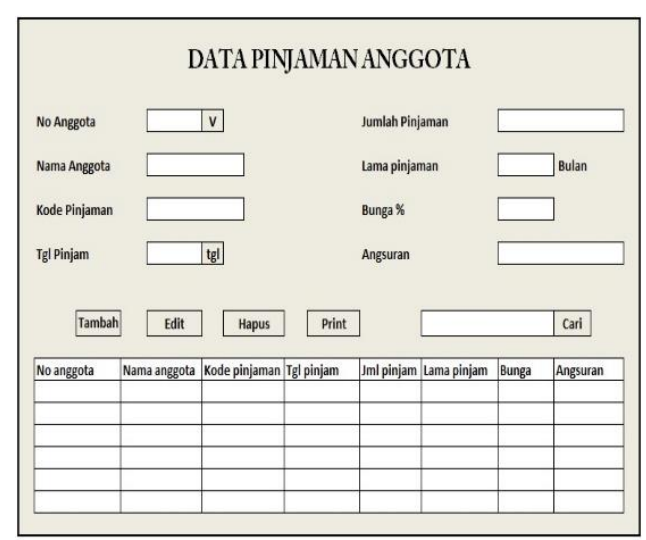

Gambar 6 Form Input Data Pinjaman

\section{KESIMPULAN}

Dengan dibuatnya sistem koperasi ini diharapkan koperasi PT Non Ferindo Utama dapat memberikan kemudahan dalam menyajikan laporan koperasi bagi perusahaan, memberikan kemudahan bagi staff dalam melakukan proses administrasi koperasi. Dan pembuatan aplikasi sistem koperasi ini dengan menggunakan Bahasa pemrograman Java

\section{REFERENSI}

[1] Dwi Prastowo, (2005). Kamus Besar Bahasa Indonesia Edisi Ketiga. Jakarta: Balai Pustaka

[2] Gordon B Davis. (1991). Sistem Informasi Manajemen, Jakarta: PT. Gramedia

[3] Jogiyanto H,M, (1999). Analisis dan Desain Sistem Informasi, Yogyakarta: Andi
[4] Ladjamuddin, Albahra.2004 Konsep Sistem Basis Data dan Implementasinya. Graha Ilmu.Yogyakarta

[5] Raymond McLeod, (2001). Sistem Informasi Edisi 7 Jilid 2.Jakarta: Prenhallindo

[6] Abdul Kadir. 2003. Pengenalan Sistem Informasi. Yogyakarta, Andi

[7] Jogianto, Metodologi Penelitian Sistem Informasi. Penerbit Andi. Yogyakarta, 2008. 